\title{
THE ANOMALY OF CONTEMPT IN THE FACE OF THE COURT RECORD
}

\author{
A. Vijayalakshmi Venugopal \& Kamal Halili Hassan \\ Universiti Kebangsaan Malaysia
}

\begin{abstract}
Categories and forms of contempt of court are not closed, whereby, judges have the discretion to use this power when they deem appropriate. However, there are a number of traditional categories that have been created and used by the courts in Malaysia and the United Kingdom. Contempt in the face of the court record has not been a traditional category of contempt in either country, and, thus far, has only been recognised in Malaysia in one case. The aims of this paper are to consider what the scope of contempt in the face of the court record is, when it should apply and whether this category is clearly distinct from the other existing categories of contempt of court. It is suggested that it may not have been necessary to create the category of contempt in the face of the court record as there appears to be an overlap between this category and the other categories of contempt of court.
\end{abstract}

Keywords: contempt of court, contempt in the face of the court record.

\section{Introduction}

Moskovitz ${ }^{1}$ wrote, "contempt of Court is the Proteus of the Legal World, assuming an almost infinite diversity of forms". While contempt of court may be difficult to define as the courts are given the discretion to apply this power when the court deems fit, there are still some traditional categories of contempt of court including disobeying a court order, scandalising the court, sub judice, contempt in the face of the court and interfering with the work of court officers. Contempt of court in Malaysia stems from the United Kingdom. Steve Shim CJ of the Federal Court in Zainur bin Zakaria v. Public Prosecutor ${ }^{2}$ acknowledged this link by stating, "now,

1 Moskovitz, Joseph, 'Contempt of Injunctions, Civil and Criminal' (1943) 43 Columbia Law Review 780, at page 780.

2 [2001] 3 MLJ 604, at page 609. 
this peculiar English concept [contempt of court] is applicable in Malaysian law ...”. The traditional categories above are recognised both in Malaysia and the United Kingdom.

The categories of contempt of court have not been authoritatively defined by statute. As such, it is left to the courts to clarify these categories. The traditional categories of contempt of court listed above have been recognised in a number of Malaysian cases by courts, including superior courts. For example disobeying a court order has been recognised by the High Court, ${ }^{3}$ the Court of Appeal, ${ }^{4}$ the Supreme Court $^{5}$ and the Federal Court; ${ }^{6}$ scandalising the court has been considered by the High Court, ${ }^{7}$ Court of Appeal ${ }^{8}$ and Supreme Court; ${ }^{9}$ sub judice has been recognised by the High Court; ${ }^{10}$ the Court of Appeal ${ }^{11}$ and Federal Court: ${ }^{12}$ contempt in the face of the court has been recognised by the High Court, ${ }^{13}$ the Court of Appeal, ${ }^{14}$ the Supreme Court, ${ }^{15}$ the Federal Court; ${ }^{16}$ and interfering

3 Such as in Kamawang Enterprise Sdn. Bhd. \& Anor. v. Mascom (M) Sdn. Bhd. \& Anor. [2009] 10 CLJ 180 and Fortune Pacific Engineering Co. Ltd. v. Gajatakraw Industries Sdn. Bhd. [2010] 5 CLJ 590.

4 Such as in John Kee v. Yap Leong Swee (1954) SNBBSCR 57 and Hardial Singh Sekhon v. PP [2009] 5 CLJ 101.

5 Such as in Wee Choo Keong v. MBf Holdings Bhd. \& Anor. and Another Appeal [1993] 2 MLJ 217.

6 Such as in T.O. Thomas v. Asia Fishing Industry Pte. Ltd. [1977] 1 MLJ 151 and Chai Tze Foh \& Anor. v. Asia Fishing Industry Pte. Ltd. [1993] 2 MLJ 217.

7 Such as in Public Prosecutor v. S.R.N. Palaniappan \& 2 Others (1949) 15 MLJ 246 and Karam Singh Veriah v. Karpal Singh [1988] 2 MLJ 603.

8 Such as in Murray Hiebert v. Chandra Sri Ram [1999] 4 MLJ 321.

9 Such as inAttorney-General v. Arthur Lee Meng Kuang [1987] 1 MLJ 206 and Trustees of Leong San Tong Khoo Kongsi (Penang) Registered \& Ors v. S.M. Idris \& Anor and Another Application[1990] 1 MLJ 273.

10 Such as in Public Prosecutor v. Abdul Samad bin Ahmad \& Anor. (1953) 19 MLJ 118 and Attorney-General v. D. Aloysius Stephens and Another (1957) SNBBSCR 58.

11 Such as in Lo Kwock Chuen v. Attorney-General (1959) SNBBSCR 112.

12 Such as in Loot Ting Yee v. Tan Sri Shiekh Hussain bin Sheikh Mohamed \& Ors. [1982] 1 MLJ 142.

13 Such as in Public Prosecutor v. Lee Ah Keh \& Ors. [1968] 1 MLJ 22 and Matthias Chang Wen Chieh v. American Express (Malaysia) Sdn. Bhd.[2010] 6 CLJ 707.

14 Such as in Woodsville Sdn. Bhd. v. Tien Ik Enterprises Sdn. Bhd. \& Ors. [2009] 3 MLJ 191.

15 Such as in In Re Puteh [1910] 11 SSLR 78 and Public Prosecutor v. Seeralan [1985] 2 MLJ 30.

16 Such as in Jaginder Singh \& Ors. v. Attorney-General[1983] 1 MLJ 71 and Zainur bin Zakaria v. Public Prosecutor [2001] 3 MLJ 604. 
with the work of court officers by the High Court ${ }^{17}$ and the Supreme Court. ${ }^{18}$ These traditional categories are also recognised by cases in the United Kingdom collated by authors in textbooks. This extends to disobedience of court orders, ${ }^{19}$ scandalising the court, ${ }^{20}$ sub judice, ${ }^{21}$ contempt in the face of the court ${ }^{22}$ and interference with persons officially connected with the court. ${ }^{23}$ While the courts may not be limited to these categories, there is some consistency in the recognition of these traditional categories. This article intends to focus on 'contempt in the face of the court record' and consider

17 Such as in Dato' Abdullah Hishan bin Hj Mohd Hashim v. Sharma Kumari Shukla[2000] 7 MLJ 667 and Chow Sooi Cheng v. Trans-Global Agencies Bhd. \& Ors. [2003] 6 CLJ 369.

18 Such as in Tai Kwong Goldsmiths \& Jewellers (under receivership) v. Yap Kooi Hee \& Ors.[1995] 1 MLJ 1.

19 C. J. Miller, 'Contempt of Court', Oxford University Press, 3rd ed., 2000, at page xxii; Lord Mackay of Clashfern, 'Contempt of Court', Halsbury's Laws of England, Sweet \& Maxwell, 4th ed. reissue, vol. 9(1), 1998, at page 239; Nigel Lowe and Brenda Sufrin, The Law of Contempt, Butterworths, 3rd ed., 1996, at page xi; Sir David Eady and A.T.H. Smith, Arlidge, Eady \& Smith on Contempt, Sweet \& Maxwell, 2nd ed., 1999, at pages xxxii-xxxiii prefer to classify civil contempt as breaches of court orders generally and Mareva Injunctions and Anton Piller Orders separately.

20 C. J. Miller, 'Contempt of Court', Oxford University Press, 3rd ed., 2000, at page xxi; Lord Mackay of Clashfern, 'Contempt of Court', Halsbury’s Laws of England, Sweet \& Maxwell, 4th ed. reissue, vol. 9(1), 1998, at page 239; Nigel Lowe and Brenda Sufrin, The Law of Contempt, Butterworths, 3rd ed., 1996, at page $\mathrm{x}$ and Sir David Eady and A.T.H. Smith, Arlidge, Eady \& Smith on Contempt, Sweet \& Maxwell, 2nd ed., 1999, at page xx.

21 C. J. Miller, 'Contempt of Court', Oxford University Press, 3rd ed., 2000, at pages xviii-xix; Lord Mackay of Clashfern, 'Contempt of Court', Halsbury's Laws of England, Sweet \& Maxwell, 4th ed. reissue, vol. 9(1), 1998, at page 239; Nigel Lowe and Brenda Sufrin, The Law of Contempt, Butterworths, 3rd ed., 1996, at page x and Sir David Eady and A.T.H. Smith, Arlidge, Eady \& Smith on Contempt, Sweet \& Maxwell, 2nd ed., 1999, at page xix.

22 C. J. Miller, 'Contempt of Court', Oxford University Press, 3rd ed., 2000, at page xv; Sir David Eady and A.T.H. Smith, Arlidge, Eady \& Smith on Contempt, Sweet \& Maxwell, 2nd ed., 1999, at pages xxvi-xxviii, Nigel Lowe and Brenda Sufrin, The Law of Contempt, Butterworths, 3rd ed., 1996, at page ix and Lord Mackay of Clashfern, 'Contempt of Court', Halsbury's Laws of England, Sweet \& Maxwell, 4th ed. reissue, vol. 9(1), 1998, at page 239.

23 C. J. Miller, 'Contempt of Court', Oxford University Press, 3rd ed., 2000, at page xxi; Lord Mackay of Clashfern, 'Contempt of Court', Halsbury's Laws of England, Sweet \& Maxwell, 4th ed. reissue, vol. 9(1), 1998, at page 239, Nigel Lowe and Brenda Sufrin, The Law of Contempt, Butterworths, 3rd ed., 1996, at pages x-xi and Sir David Eady and A.T.H. Smith, Arlidge, Eady \& Smith on Contempt, Sweet \& Maxwell, 2nd ed., 1999, at pages xxx-xxxi. 
how this category fits with the other existing categories of contempt of court.

\section{Existing Categories of Contempt of Court}

Categories of contempt of court have been defined and refined by many judges in many cases. It is not attempted here to present a comprehensive review of all these explanations, but rather a sample of some of them to give an indication of what these categories are intended to encompass and how they differ from each other. The categories discussed below are those that have been recognised by the Malaysian courts.

The first category of contempt of court is disobeying a court order. Azahar Mohamed J. of the High Court in MediaCorp News Pte. Ltd. \& Ors. v. MediaBanc (Johor Bahru) Sdn. Bhd. \& Ors. (Lim Leong Wuoh \& Ors., proposed contempt parties ${ }^{24}$ explained that contempt of court by disobeying a court order involves proving that “ ...the proposed contempt parties had wilfully, deliberately disobeying, or disregarding the order of the court”. A properly instituted court must have issued a court order, which an alleged contemnor does not obey. Low Hop Bing J. commented in Arab-Malaysian Prima Realty Sdn. Bhd. v. Sri Kelangkota-Rakan Engineering J.V. Sdn. Bhd. \& Ors. ${ }^{25}$ that public policy and public interest demand the law of contempt of court in order to ensure, for example, that court orders are fulfilled and the 'due administration of justice is not put in jeopardy'.

The next category relates to evading service of a court order. Chong Siew Fai C.J. (Sabah and Sarawak) ${ }^{26}$ explained in Wee Choo Keong v. MBf Holdings Bhd. \& Anor. and Another Appeal ${ }^{27}$ that, "deliberate or intentional evasion of service of an injunction order of court thereby constituting an interference with the administration of justice is a contempt of court, and is punishable not for the purpose of vindicating the dignity of the court, but to prevent the improper

24 [2010] 5 MLJ 562, at page 564.

25 [2000] 2 CLJ 632, at page 641.

26 A dissenting judgment in the case, though the majority still recognised this category of contempt.

27 [1995] 3 MLJ 549, at page 563. 
interference". ${ }^{28}$ Again, a court must have issued a court order, which is then intentionally avoided by evading service thereof.

The following category is breaching an undertaking. Abdul Malik bin Ishak J. of the High Court in Md Amin bin Md Yusof \& Anor. v. Cityvilla Sdn. Bhd ${ }^{29}$ observed that an undertaking to the court in the course of proceedings should not be treated lightly. Such an undertaking is often equated with an injunction, and, hence, it may be enforced by committal. This category requires an undertaking to be given to the court by the alleged contemnor, which is then breached.

The following category is scandalising the court. The Supreme Court in Trustees of Leong San Tong Khoo Kongsi (Penang) Registered \& Ors v. S.M. Idris \& Anor and Another Application ${ }^{30}$ noted that, "the blatant insinuations made by them had scandalized the Supreme Court and brought it into disrepute as they were not within limits of reasonable courtesy and good faith”. What is required is unwarranted and discourteous criticisms of the legal system, which 'tended to prejudice' the administration of justice. ${ }^{31}$

Another category is sub judice. The Federal Court in Loot Ting Yee v. Tan Sri Shiekh Hussain bin Sheikh Mohamed \& Ors. ${ }^{32}$ clarified that, "we feel that the real question for the court in this case is to decide whether there is contempt, is whether the risk of prejudice to a fair and proper trial of the pending legal proceedings is serious or real or substantial”. This category involves commenting on pending legal proceedings, which tends to prejudice a fair and proper trial of these proceedings.

28 The Supreme Court of India in The Aligarg Municipality Board and Others v. Ekka Tonga Mazdoor Union and Others A.I.R. (1970) S.C. 1767, at page 1770, similarly observed, "Contempt proceeding against a person who has failed to comply with the Court's order serves a dual purpose: (1) vindication of the public interest by punishment of contemptuous conduct and (2) coercion to compel the contemnor to do what the law requires of him. The sentence imposed should effectuate both these purposes".

29 [2004] 4 AMR 449, at page 46.

30 [1990] 1 MLJ 273, at page 277.

31 Judge of the Court of Appeal, Ahmad Fairuz and Judge of the Court of Appeal, Denis Ong in Murray Hiebert v. Chandra Sri Ram [1999] 4 MLJ 321, at pages 332-336 and 359, respectively.

32 [1982] 1 MLJ 142, at page 147. 
The next category is contempt in the face of the court. Zulkefli J. of the High Court in Koperasi Serbaguna Taiping Barat Bhd v. Lim Joo Thong ${ }^{33}$ opined that contempt in the face of the court related to contempt in the court's cognisance. This category is quite diverse. It was added that there is no 'rigid formula' on what constitutes this category of contempt, although it should involve words or actions that tend to interfere with the course of justice. It was also pointed out that, “ ...it appears unnecessary that the act of contempt should take place wholly, or in part in a court room itself nor does it seem to be necessary that all the circumstances of the contempt should be within the personal knowledge of the judicial officer dealing with the contempt”. This category seems to traditionally arise when contempt of court is committed in a court's presence, but is not limited to this geographical context.

The next category is interference with the work of court officers. V.C. George J. of the Supreme Court observed in Tai Kwong Goldsmiths \& Jewellers (under receivership) v. Yap Kooi Hee \& Ors. ${ }^{34}$ that, "it is trite that a court-appointed receiver is an officer of the court and accordingly, any interference with him or with property under his control constitutes a contempt of court". It was added that as a general principle, " ...interference with persons having duties to perform in or at the instance of a court of justice amounts to contempt of court”. This category appears to stem from interfering with the work of any court appointed officer.

These categories appear to be too narrow to include the form of contempt that arose in the case below since another category of contempt was created and expressly distinguished from contempt in the face of the court. It will be discussed further below whether this category of contempt was necessary and distinctive, not just from contempt in the face of the court, but also compared to the other categories of contempt of court. The case below seems to mark the rise of a new category of contempt of court.

\section{The Emergence of Contempt in the Face of the Court Record}

In Anthony Ratos s/o Domingos Ratos v. City Specialist Centre Sdn. Bhd. (t/a City Medical Centre) (Attorney General, Intervener), ${ }^{35} \mathrm{a}$

33 [1999] 6 MLJ 38, at pages 54-55.

34 [1995] 1 MLJ 1.

35 [1996] 3 MLJ 349, at page 356. 
lawyer and his client were alleged to be in contempt of court for initiating committal proceedings against the Honourable R.K. Nathan J.C. who had given an order to strike out the client's petition in Dr. Leela Ratos \& Ors. v. Anthony Ratos s/o Domingo Ratos \& Ors. ${ }^{36}$ K.L. Rekhraj J.C. of the High Court considered whether a lawyer and his client should be found guilty and sentenced for contempt of court. Counsel for the client questioned the jurisdiction of the court to hear these charges as the court can only take action on its own motion where the act of contempt was committed in the face of the court. The court overruled the objection and responded that it had the power to act on its own motion as these contempt proceedings arose out of the collateral contempt proceedings against R.K. Nathan J.C. in the earlier case. K.L. Rekhraj J.C. responded that “...these contempt proceedings arose out of the collateral contempt proceedings which were before this court in committing the judicial commissioner for contempt and are therefore proceedings arising out of the same cause. Therefore, the act complained of is an act in the face of the court record." ${ }^{37}$

The court explained that it had the power to act on its own motion under Order 52, rule 4 of the Rules of the High Court 1980 against a person guilty of contempt of court and Order 52, rule 1(3) of these Rules empowered a High Court judge to issue an order of committal “...in connection with any proceedings in the High Court...". The court therefore held that it has the power to punish on its own motion, contempt "...in the face of the court (ex facie) or otherwise..." ${ }^{38} \mathrm{On}$ the facts, the court imposed a fine of RM10,000 or imprisonment for three months in default of payment of the fine for each of the contemnors, ${ }^{39}$ but warned that for future cases where the contempt was 'grave', as here, a custodial sentence would be imposed. The court was moved by the intervention of the Attorney General to show mercy in this case. ${ }^{40}$

\section{Considering the Scope of this New Category of Contempt}

It is submitted that the court's interpretation of the Rules above validly empowers the court to act on its own motion where any

\footnotetext{
36 [1996] 3 MLJ 167.

37 [1996] 3 MLJ 349, at page 356.

38 Ibid.

39 [1996] 3 MLJ 349, at page 360.

40 Ibid.
} 
form of contempt of court is allegedly committed in relation to proceedings before the High Court. Order 52, rules 1(3) and 4 are not limited to contempt in the face of the court. The former rule permits contempt proceedings in 'connection' to any proceedings before the High Court and the latter rule recognises the High Court's power to initiate contempt proceedings on its own motion. Order 1, rule 2(1) provides that these Rules apply to all proceedings in the High Court. Therefore, for these Rules to be applied, the proceedings must be in 'connection' to proceedings before the High Court. Additionally, for contempt proceedings to be initiated before the High Court, it is likely that the contempt arose in connection to proceedings before this court.

What is then not very clear is what is meant by this new category of contempt in the face of the court record. If this category was meant to be different from contempt in the face of the court, then does this new category encompass all other forms of contempt, as long as it does not occur in the face of the court, such as disobeying a court order granted by the High Court, scandalising the High Court or High Court judge and sub judice in relation to pending High Court proceedings? If contempt in the face of the court record only means that the contempt must have occurred in 'connection' with proceedings before the High Court, this could overlap with disobeying a court order, scandalising the court and sub judice.

The court imposed quite a high fine in this case and even then, K.L. Rekhraj J.C. stated he was being lenient. It would then be important to clarify the form of contempt committed. Were the contemnors in contempt for alleging that R.K. Nathan J.C. committed contempt of court by striking out the client's petition in Dr. Leela Ratos \& Ors. v. Anthony Ratos s/o Domingo Ratos \& Ors.? If so, what form of contempt was involved here? If the contemnors made unfairly critical remarks about R.K. Nathan J.C.'s decision, this may be scandalising the court. K.L. Rekhraj J.C. explained the form of contempt in this case in the following terms:

This court had looked at this contempt by Mr Murthit and his client to cite a judicial commissioner as an act of deliberate and contumelious conduct sufficient to warrant a serious penalty of imprisonment to vindicate

41 The lawyer who was alleged to have committed contempt of court in this case. 
its own dignity, to enforce obedience to its mandates and to protect its officers and to shield those who are entrusted to its care from such scurrilous attacks; for without such deterrent punishment or the protection of the law, the court of justice would sooner or later loose its hold of the public respect; and with it the maintenance of law and order would be rendered impossible. ...drew his 'sword' and charged himself into the arena of court to challenge the authority of the judge by taking the contempt proceedings against him $^{42}$ to commit him to prison. His drawn sword was met by a 'shield'-the provisions of $s 14$ of the Courts of Judicature Act ${ }^{43}$-and the sword of punishment .... ${ }^{44}$

Section 14 of the Courts of Judicature Act 1964 relates to judicial immunity for civil suits and costs, but does not specifically include liability for contempt of court. This extension of privilege was not explored by the court. Additionally, this section does not appear to warrant a finding of contempt for raising contempt against a judge. It was also not further clarified whether raising contempt against a judge in the performance of his judicial duties would expose the applicant to contempt liability in every case or because of distinctive features in this case, such as the application being 'deliberate'. An application to cite a judge for contempt of court would probably be 'deliberate' in most cases. It was not clarified why this application was 'contumelious'; was it such because the application was brought or perhaps disrespectful phrasing of the application? There were no cases cited as authorities in the judgment to help relate these findings to other forms and cases concerning contempt of court.

The category of contempt in the face of the court record, as explained in this case, appears to cover any form of contempt not committed in the presence of the court. This may clarify how the alleged contempt

42 R.K. Nathan J.C.

43 Section 14(1) of the Courts of Judicature Act 1964 provides that, "No judge or other person acting judicially shall be liable to be sued in any civil court for any act done or ordered to be done by him in the discharge of his judicial duty, whether or not within the limits of his jurisdiction, nor shall any order for costs be made against him, provided that he at the time believed himself to have jurisdiction to do or order the act complained of".

44 [1996] 3 MLJ 349, at page 357. 
came to the court's notice, but does not seem to clarify what was the form of the misconduct alleged. Thus, the form of contempt within this category still appears to be uncertain.

\section{Recommendations}

This new category appears to have been referred to in response to the preliminary objection that a court can only initiate contempt proceedings on its own motion for contempt in the face of the court. It is suggested that the court fairly pointed out that this objection is not valid based on the relevant Rules of the High Court 1980.

It is submitted that to interpret this category so broadly as to encompass any contempt proceedings arising in connection to other legal proceedings before the court is unnecessarily confusing as it would seem to include all other categories (disobeying a court order, evading service of a court order, breaching an undertaking, scandalising the court, sub judice and interfering with the work of court officers), merely to distinguish these categories from contempt in the face of the court. Court proceedings would be necessary to issue the court order, require the undertaking, giving rise to scandalous or sub judice comments and involving the work of court officers, hence, potentially, all of these categories could be included in contempt in the face of the court record with this interpretation.

It is suggested that it would be clearer to have more specific categories of contempt to more clearly distinguish the forms of contempt of court involved rather than including most of these categories within a substantially broader category. Additionally, as pointed out earlier, ${ }^{45}$ even contempt in the face of the court, has been extended to contempt not necessarily committed in the court's presence, and so, may arise in connection with court proceedings. As such, even this category may overlap with contempt in the face of the court record if this latter category merely needs to arise in connection with other court proceedings.

The contempt of court that arose in the case of Anthony Ratos appears to be where the client and lawyer initiated proceedings for striking out the client's petition. It is not clear how far advanced

45 Zulkefli J. of the High Court in Koperasi Serbaguna Taiping Barat Bhd v. Lim Joo Thong [1999] 6 MLJ 38, at pages 54-55. 
the lawyer and client had taken their contempt proceedings against the judge. However, since they were stated to have arisen from “... the collateral contempt proceedings which were before this court... $"{ }^{46}$ these contempt proceedings were already initiated. Since the proceedings were already before the court in this case, at least where the application to cite the judge for contempt was already made, it is submitted that the judge hearing this contempt application could proceed to punish the contemnors for contempt in the face of the court.

Contempt in the face of the court can arise where the court is insulted. Abdoolcader J. of the High Court in Re Kumaraendran, An Advocate \& Solicitor ${ }^{47}$ commented, “...insulting and contumacious behaviour in outrageous and provocative language tantamount to a deliberate challenge to the authority of a learned president and clearly a gross contempt in the face of the court". To fall within this form of contempt, it would have been clearer to point to specific words or phrases in the application to cite the judge for contempt that were found to be discourteous and disrespectful. If there were no such phrases, and, instead, objection taken to where parties attempt to cite judges for contempt for discharging their lawful duties, this could have been explained to constitute contempt in itself.

It is argued that merely applying for judges to be cited for contempt should not constitute contempt of court itself as long as the written and/or applications and submissions are expressed with due courtesy and respect. Such an application can be dismissed if not valid, but as long as courteously made, perhaps the court should discuss the merits of the application rather than just dismissing it without hearing, especially since the judicial immunity in section 14 of the Courts of Judicature Act 1964 does not seem to extend to allegations of contempt of court.

If the client's application to cite the judge for contempt was submitted, but not yet before the court to be argued further and the court felt that it were important to hold this application as contempt of court,

46 K.L. Rekhraj J.C. of the High Court in Anthony Ratos s/o Domingos Ratos v. City Specialist Centre Sdn. Bhd. (t/a City Medical Centre) (Attorney General, Intervener) [1996] 3 MLJ 349, at page 356.

47 [1975] 2 MLJ 45, at page 47. This case was cited by the Federal Court in Jaginder Singh \& Ors. v. Attorney-General [1983] 1 MLJ 71, at page 74 and the Supreme Court in Public Prosecutorv. Seeralan [1985] 2 MLJ 30, at page 33. 
any discourteous or disrespectful words in the application could be held as contempt by scandalising the court or even sub judice contempt if the words tended to prejudice the fair trial of any further pending proceedings. A judge is also a court officer, so alleging contempt of a judge could even be interpreted as interfering with the work of court officers if the allegation had the effect of interfering with the work of the judge in any way. There did not appear to be any court order which was disobeying or evading service thereof, or any undertaking that was breached to justify these categories of contempt being involved.

It does not appear to be very clear from the report of this case what form of contempt was involved and at what stage the contempt application was made against the judge that gave rise to contempt proceedings against the applicant and his lawyer. However, it is submitted that it may not have been necessary to create a new category of contempt that does not appear to be distinctly different from contempt in the face of the court, or any of the other categories of contempt. Arguably, the facts of this case could have also fallen within the existing categories of contempt.

\section{Conclusion}

K.L. Rekhraj J.C. of the High Court appeared to create a new genus of contempt of court known as 'contempt in the face of the court record'. The court did not seem to give any authority for this particular term. In addition, this term does not seem familiar in contempt of court in the United Kingdom ${ }^{48}$ or even India. ${ }^{49}$ Additionally, thus

48 As per Nigel Lowe and Brenda Sufrin, The Law of Contempt, Butterworths, 3rd ed., 1996; Lord Mackay of Clashfern, 'Contempt of Court', Halsbury's Laws of England, Sweet \& Maxwell, 4th ed. reissue, vol. 9(1), 1998; Sir David Eady and A.T.H. Smith, Arlidge, Eady \& Smith on Contempt, Sweet \& Maxwell, 2nd ed., 1999 and C. J. Miller, Contempt of Court, Oxford University Press, 3rd ed., 2000.

49 As per Bal Raj Varma, Law of Contempt in India, Bombay: N.M. Tripathi Private Limited, 1974; Justice S.R. Roy, The Contempt of Courts Act 1971, Calcutta: Kamal Law House, 1996; Justice V.R. Krishna Iyer \& R.P. Srivastava, K.J. Aiyar's Law of Contempt of Courts, Legislatures and Public Servants, Allahabad: The Law Book Company (P) Ltd., 9th ed., 1997; P.S. Narayana, Law of Contempt, Hydrebad: Asia Law House, New Edition, 1998; Justice S.K. Mookerji, Iyer's Law of Contempt of Courts with Parliament, State Assemblies \& Public Servants, 2nd ed., Delhi Law House, 1999; Samaraditya Pal, The Law of Contempt, Law Research Institute, 3rd ed., 2001; Vepa P. Sarathi, G.C.V. Subha Rao's Commentary on Contempt of Courts Act 1971, Hydrebad: ALT Publications, 2001 and Justice V.K. Mehrotra, V.G. Ramachandran's Contempt of Court, Eastern Book Company (India), 6th ed., 2002. 
far, this category has not yet been adopted or applied in any other reported Malaysian case since.

This new category may have been created to clarify that the court may initiate contempt proceedings in cases other than contempt in the face of the court. However, this point could have been made without this new category being created, as the new category, without further clarification of its scope, raises further questions of how and when it was intended to apply.

This was obviously a serious form of contempt as indicated by the severity of the fine imposed. This case raised intriguing points, which, unfortunately, were not fully explained in the report of the case. Raising the new and unusual category of contempt seems to have also raised more questions than answers concerning the scope and intended application of this new category. This may explain why this new category has not since been applied in any other reported case in Malaysia. It is not a typical category of contempt of court in Malaysia or the United Kingdom, and thus, remains an anomaly in the law on contempt of court in Malaysia.

It is acknowledged that judges have and would need the discretion to create new categories of contempt of court when the need arises in dealing with the multitude of cases and factual variations confronting them. However, it is submitted that when a new category of contempt of court is created, particularly one that is lacking in precedent, such category should be clearly explained in terms of how does it differ from existing categories, why it is necessary to punish such a form of contempt and when should such a category be used in future cases. This is important to help clarify how this category is intended to apply for the courts to uphold justice in this and future cases. 